\title{
高齢透析患者および障害を持つ透析患者の施設入所について
}

$\begin{array}{lrrrrrrrr}\text { 小野 } & \text { 満也 } & \text { 澤 } & \text { 仁子 } & \text { 長谷 } & \text { 蔦枝 } & \text { 小林 } & \text { 和男 } \\ \text { 水間 } & \text { 順子 } & \text { 宮沢 } & \text { 初 江 } & \text { 小池 } & \text { 桃子 } & \text { 池添 } & \text { 正哉 } \\ \text { 山口 } & \text { 博 } & \text { 佐 藤 } & \text { 博司 } & & & & & \end{array}$

key words : 血液透析, 高齢患者, 精神身体障害者, 施設入所

〈要旨〉

当院の血液透析患者中, 高齢および精神身体に障害をもつ患者は, 昭和 62 年には 22 例（血液透析患者 98 例中 $22.5 \%)$, 平成 5 年には 43 例 $(120$ 例中 $35.8 \%)$, 平成 6 年には 47 例（140 例中 $33.6 \% ）$ と増加しており, 血液透 析に通院することが困難な患者のうち，6 例が 4 つの施設に入所していた. 施設のスタッフ 85 名に対してアンケー 卜調査を行ったところ, 透析患者に対して $74 \%$ 「食事・水分管理」「緊急時の対処」「シャント管理」などに不安 を感じており，「通院送迎」も負担と感じていた．すべての施設で事前に勉強会が開かれていた。通院困難な血液透 析患者は, 入院生活を送るよりも, 老人ホームなどの施設に入所しながら透析に通院するほうが生活の質は高い場 合も考えられ, 透析患者の施設入所は重要であると思われる. そのためには病院と施設とが緊密な連携を保つ必要 があると思われた.

\section{Admission of aged and handicapped hemodialysis patients to facilities}

Mitsuya Ono, Jinko Sawa, Tsutae Hase, Kazuo Kobayashi, Junko Mizuma, Hatsue Miyazawa, Momoko Koike, Masaya Ikezoe, Hiroshi Yamaguchi, Hiroshi Sato

Division of Dialysis, Naganokenkouseiren Saku Central Hospital

There were 22 aged or handicapped hemodialysis patients in our hospital in 1987 (22.5\% of the 98 hemodialysis patients), 43 in 1993 (35.8\% of the 120), and 47 in 1994 (33.6\% of the 140). It is difficult for some of them to come to the hospital themselves, and six of them were admitted to four facilities. We conducted a questionnaire survey of 85 members of the staff of these facilities. Seventy-four percent of them felt anxious concerning the admission of hemodialysis patients in terms of diet and water intake, emergencies, blood access, and/or transportation. They assessed hemodialysis before the patients' admission. The QOL of aged and handicapped hemodialysis patients without family may be better in a facility than in a hospital. To sustain better QOL of hemodialysis patients in facilities, we must maintain contact with their staff.

\section{はじめに}

血液透析患者の増加に伴って，一人で通院する ことができない高齢透析患者や障害を持つ透析患 者も増加している，通院が困難で家人の通院介助 が期待できない一人暮らしゃ老人二人世帯の血液 透析患者は，入院して透析する方法の他に，老人
ホームなどの施設に入所してそこから通院する方 法がある. 平成 6 年 5 月の時点で当院血液透析患 者 140 例中, 6 例の患者が 4 箇所の施設に入所し 通院透析を行っている. 今回私たちは, 透析患者 が入所している施設のスタッフに対してアンケー 卜調査を行い, 透析患者の施設入所の現状と問題

小野 満也 長野県厚生連佐久総合病院透析室％ 384-03 南佐久郡臼田町大字臼田 197 (0267-82-3131)

〔受付: 平成 7 年 4 月 26 日，受理：平成 7 年 7 月 27 日〕 
点について検討したので報告する ${ }^{1)}$.

\section{対象と方法}

昭和 62 年 1 月, 平成 5 年 1 月, 平成 6 年 5 月の 当院透析室における 65 歳以上の高齢の血液透析 患者抢よび精神や身体障害をもつ血液透析患者の 数とその家族状況を調べた。次に，平成 6 年度に おいて 6 例の患者が入所している 4 施設（精神薄 弱者更生施設，身体障害者療護施設，生活保護法 による救護施設，養護老人ホーム）のスタッフ計 85 名に対して, (1) スタッフの職種, (2) 血液透析患 者の施設入所に対する負担の有無, (3) その具体的

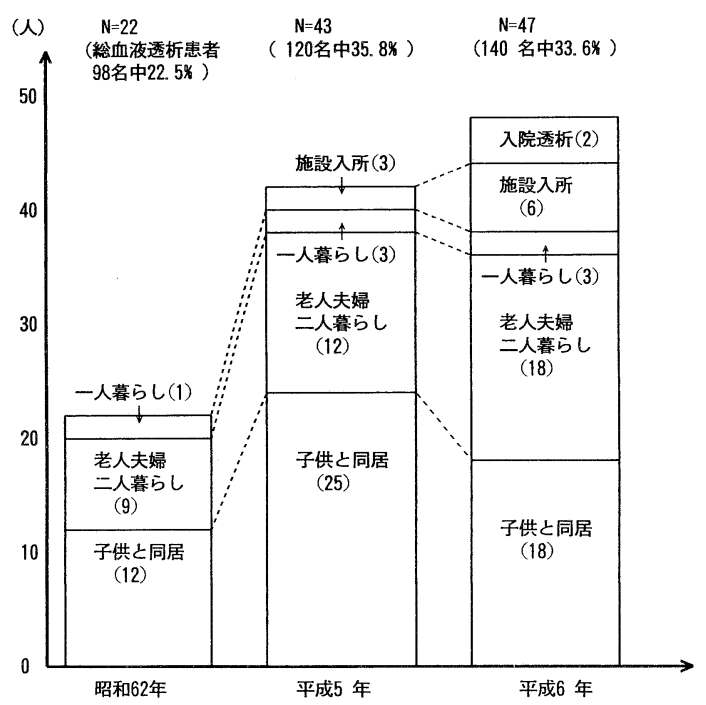

図 1 当院血液透析患者に打ける 65 歳以上の高 齢患者および精神身体障害者の家族状況
内容, (4) 受入れ後の意識変化, (5) 受入れ時の準備, の 5 点についてアンケート調査を行った。

\section{結果}

当院血液透析患者における 65 歳以上の高齢患 者および障害を持つ患者の数と家族状況を図 1 に 示す. 昭和 62 年には 22 例(総血液透析患者 98 例 中 $22.5 \%$ ）であり，一人暮らし 1 例，老人夫婦二 人暮らしが 9 例, 子供と同居しているものが 12 例 であり，施設入所患者はなかった．平成 5 年には 43 例（120 例中 $35.8 \%$ ) であり，施設入所患者は 3 例であった。平成 6 年には 47 例（140 例中 $33.6 \%$ ）であり，施設入所患者が 6 例と増加した 他，通院が困難なための入院透析も 2 例認めた.

表に施設入所中の血液透析患者 6 例の慢性腎不 全の原因疾患および施設入所の理由を示す。症例 1 から 4 は施設入所中に透析導入になった例であ り，症例 5,6 は透析導入後に施設入所した例で

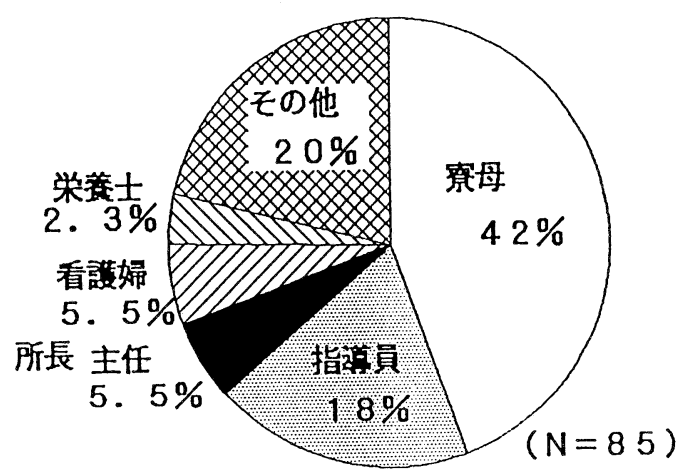

図 2 貴方の職種はなんですか

表 施設入所中の血液透析患者

\begin{tabular}{|c|c|c|c|c|c|}
\hline 症例 & 年齢 & 性別 & 慢性腎不全の原因疾患 & 入所理由 & 施設 \\
\hline \multicolumn{6}{|c|}{ [施設入所中に血液透析導入] } \\
\hline 1 & 57 歳 & 男性 & 腎硬化症 & $\begin{array}{l}\text { 脳出血による片麻瘏 } \\
\text { 家庭介護不可 }\end{array}$ & 身体障害者療護施設 \\
\hline 2 & 77 歳 & 女性 & 腎硬化症 & $\begin{array}{l}\text { 遠距離通院困難 } \\
\text { 家庭介護不可 }\end{array}$ & 養護老人ホーム \\
\hline 3 & 44 歳 & 男性 & 慢性系球体腎炎 & $\begin{array}{l}\text { 精神薄弱者 } \\
\text { 家庭介護不可 }\end{array}$ & 精神薄弱者更生施設 \\
\hline 4 & 74 歳 & 女性 & 慢性糸球体腎炎 & $\begin{array}{l}\text { 精神薄弱者 } \\
\text { 家庭介護不可 }\end{array}$ & $\begin{array}{l}\text { 生活保護法による救 } \\
\text { 護施設 }\end{array}$ \\
\hline \multicolumn{6}{|c|}{ [血液透析導入後施設入所］ } \\
\hline 5 & 70 歳 & 女性 & 糖尿病性腎症 & 介護者不在 & 養護老人ホーム \\
\hline 6 & 52 歳 & 男性 & 慢性系球体腎炎 & $\begin{array}{l}\text { 精神分裂病 } \\
\text { 家庭介護不可 }\end{array}$ & $\begin{array}{l}\text { 生活保護法による救 } \\
\text { 護施設 }\end{array}$ \\
\hline
\end{tabular}




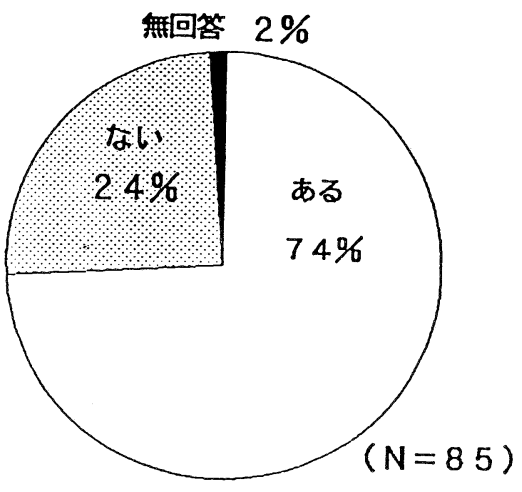

図 3 透析患者の入所および治療開始にあたって 不安・負担はありましたか

わからない

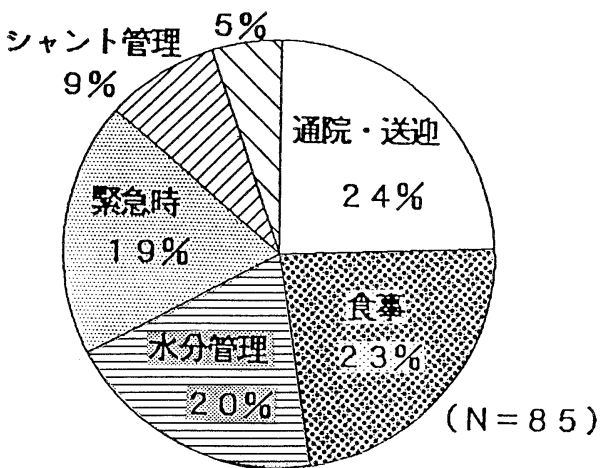

図 4 どんな不安・負担でしたか（あると答えた 人のみ)

ある，全例が家庭介護が困難かまたは介護者が不 在であり，症例 1 は脳出血による右片麻疩，症例 2 は高齢による ADL 低下に加えて遠距離のため 通院が困難, 症例 3,4 は精神薄弱者, 症例 5 は 高齢による ADL 低下のため通院が困難, 症例 6 は精神分裂病が原因であった。

4 施設のスタッフ計 85 名に対して行ったアン ケート調査の結果では，職種は，寮母 $42 \%$, 指導 員が $18 \%$ で，看護婦，栄養士は $10 \%$ あっあた(図 2 ). 透析患者への不安や負担については，「ある」 が 74\%を占めた（図 3 ）。その内容では，「通院・ 送迎」が 24\%,「食事・水分管理」があわせて $43 \%$, 「緊急時の不安」が 19\%，「シャント管理」が $9 \%$ であうた（図４）。透析患者を受け入れた後では， 「不安はなくなった」，「不安・負担はそれほどでも

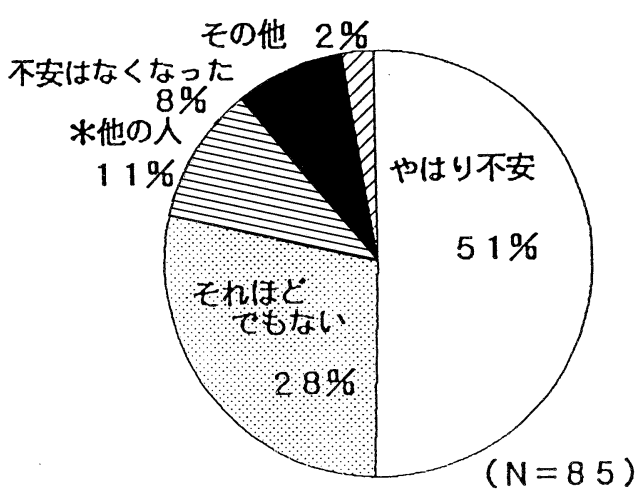

*他の人と変わらない事を指す

図 5 実際に透析患者を受け入れてどうでしたか

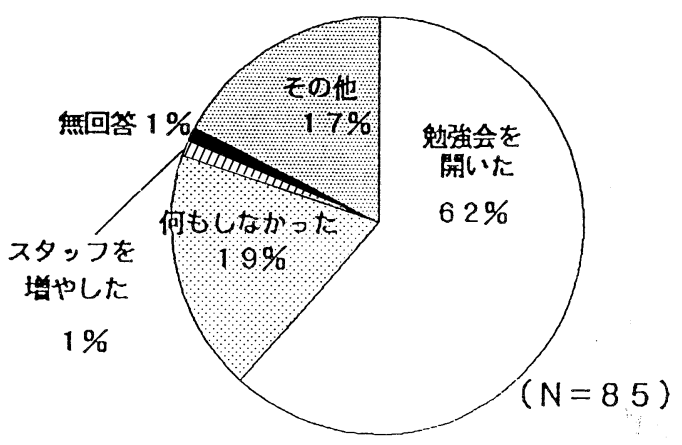

図 6 透析患者を受け入れるにあたって準備はあ りましたか

ない」，「他の入所者と変わりない」が $47 \%$ を占め たが，「やはり不安」も51\%にみられた（図 5 )。 透析患者を受け入れる準備としては，全施設が勉 強会を開いており，62\%のスタッフが参加してい た(図 6 ).

\section{考察}

透析患者の増加とともに，高齢透析患者や障害 を持つ透析患者は増加しており，特に高齢透析患 者では脳血管障害による障害を持つ患者の増加が 予想される ${ }^{2)}$. 今回の調查でも昭和 62 年には $22.5 \%$ であった高齢および障害を持つ透析患者の 割合は, 平成 5 年には $35.8 \%$ と増加していた。こ うした患者に対しては在宅療養の支援が重要であ り ${ }^{3)}$, 当院でも食事の宅配サービスの斡旋や, 地域 自治体との協力によるへルパーの派遣やデイサー 
ビス職員による透析通院送迎などを行っている. しかし家人の通院介助が期待できない一人暮らし や老人二人世帯の血液透析患者では血液透析に通 院することが困難な症例が多く, CAPD も手技的 に困難なため適応になりにくい.このためこうし た患者では入院透析となることが多い. 戸村ら ${ }^{4)}$ は患者指導と家族へのはたらきかけにより, 長期 入院から家庭復帰のできる場合があると述べてい るが，介護者がいない患者では退院することは困 難であり，リハビリなどを行っても ADL はむし ろ低下し，次第に無気力となって全身状態が悪化 していく例が多くみられる. 入院透析は通院の必 要がなく医療環境に恵まれる反面, 一生を患者と して病院で過ごすことによる生活の質 (QOL) の 低下や，長期入院による病院ベッドの占有などの 問題がある。また安易な入院透析は医療費の高騰 が叫ばれるおりからも問題であると考えられる. 通院することが困難な症例では，入院透析の他に 老人ホームなどの施設に入所してそこから通院す る方法がある。しかし透析患者を入所させ 1 週間 に 2 回ないし 3 回定期的に通院させることは施設 にとって大きな負担であり, 透析患者の施設入所 は困難である ${ }^{5,6)}$. また病院に併設された老人保健 施設への透析患者の入所は薬剤料や検查料が算定 できないなどの経済的問題がある77. 当院がある 長野県佐久地方では老人ホームのベッド数が相対 的に不足しており，一般老人でも入所に 1 年以上 の待機が必要であるが, 幸い当院血液透析患者 140 例中 6 例の患者が 4 箇所の施設に入所し通院 透析を行っている. 施設のスタッフに対して行っ たアンケート調査では，スタッフの血液透析患者 を受け入れることに対する不安が強く，実際に患 者を受け入れた後も $51 \%$ が不安を持っていた。こ の不安が, 透析患者の施設入所を妨げている最も 大きな原因と思われた。具体的には，緊急時の対 応, シャントの管理, 水分・食事管理など血液透 析患者の一般的看護の問題と, 頻回の通院 - 送迎 に対するスタッフの労力の問題が挙げられた。こ うした施設スタッフの透析患者に対する不安をな くしていくためには, 施設と透析室のスタッフが 常に患者の情報を交換し, 緊急時には常に病院が
患者を引き受ける体制が必要である．当院におい ても患者の透析来院時には施設スタッフから患者 の状態についての申し送りを受け，透析終了時に は透析室スタッフから施設スタッフへ透析中の状 態, 食事についての注意事項, 内服薬の変更など について申し送りを行っている．患者の状態に変 化があれば 24 時間体制で連絡を受け，必要に応じ て入院としている.また透析患者の施設入所にあ たっては,ソーシャルケースワーカーの役割は大 きく，施設や行政へのはたらきかけが不可欠であ $3^{8)}$. ソーシャルケースワーカーと透析室スタッ フとの院内の緊密な連絡体制も重要と思われた. また受け入れを拒む公的施設も少なからずあるた め, 高齢透析患者や障害を持つ透析患者の入院透 析, 施設入所の実態について全国的規模で把握し， 行政側にはたらきかけていくことが重要と考えら れた。

\section{結語}

介護者がおらず血液透析に通院することが困難 な高齢患者, 精神身体に障害を持つ患者では, 入 院透析の他に施設に入所して透析に通院する方法 があり，患者の生活の質を向上させる上から好ま しい場合がありうると思われた，血液透析患者の 施設入所を継続していくためには，施設と病院と が緊密な連携を保ってゆくことが必要であると考 えられた。

本論文の要旨は第 39 回日本透析医学会総会 (1994 年大阪）に抢いて発表した。

\section{文献}

1）小林和男, 長谷蔦枝, 澤 仁子, 関 郁男, 水 間順子，宮沢初江，小池桃子：透析患者の施設 入所の現状と問題点. 透析会誌 27 (Suppl 1)： 858, 1994

2) 石田正矩, 後藤武男, 永井博之, 宮本 孝, 寺 山一徳, 申 曽洙, 坂井瑠実, 原 信二: 高齢 者透析患者における運動障害の実態一兵庫県下 60 施設におケるアンケート調査の結果をもと に一。透析会誌 $24 ： 1243-1247,1991$

3）佐々木いく, 上林多代, 岩沢恵美子, 返田英子, 遠藤ミネ子, 長根 裕, 細川久昭：当院に扔け 
る高齢透析患者への対応. 透析会誌 $23 ： 1109$ 1112, 1990

4）戸村成男, 長野久子, 小林繁郎, 柴田道子, 中 村義弘，浅川千秋，皿田敏明，千田佳子：高齢 透析患者の長期入院に関連する因子一長期入院 の看護面からの解決法一. 透析会誌 $26: 1535-$ 1538, 1993

5）三木慶治：要介護の長期入院透析患者への社会 保障の展望. 透析会誌 28 (Suppl 1)：528, 1995

6）木原和美：高齢透析患者の社会的不安と社会保
障について. 透析会誌 28 (Suppl 1)：528, 1995

7）佐々木裕, 藤井ひとみ, 山田三代子, 昆野 典, 佐藤靖子, 金沢重俊：老人保健施設による高齢 透析患者の管理. 透析会誌 28 (Suppl 1)：658, 1995

8）牛田由美子, 加藤康子, 大島理恵：慢性腎不全 患者の quality of life について一社会保障・福 祉サービスの必要性一. 透析会誌 $24: 533-536$, 1991 